Being a good senior manager in Indigenous community governance: Working with public purpose and private benefit

W. Sanders

DISCUSSION PAPER No. 280/2006

ISSN 10361774

ISBN 0731556550

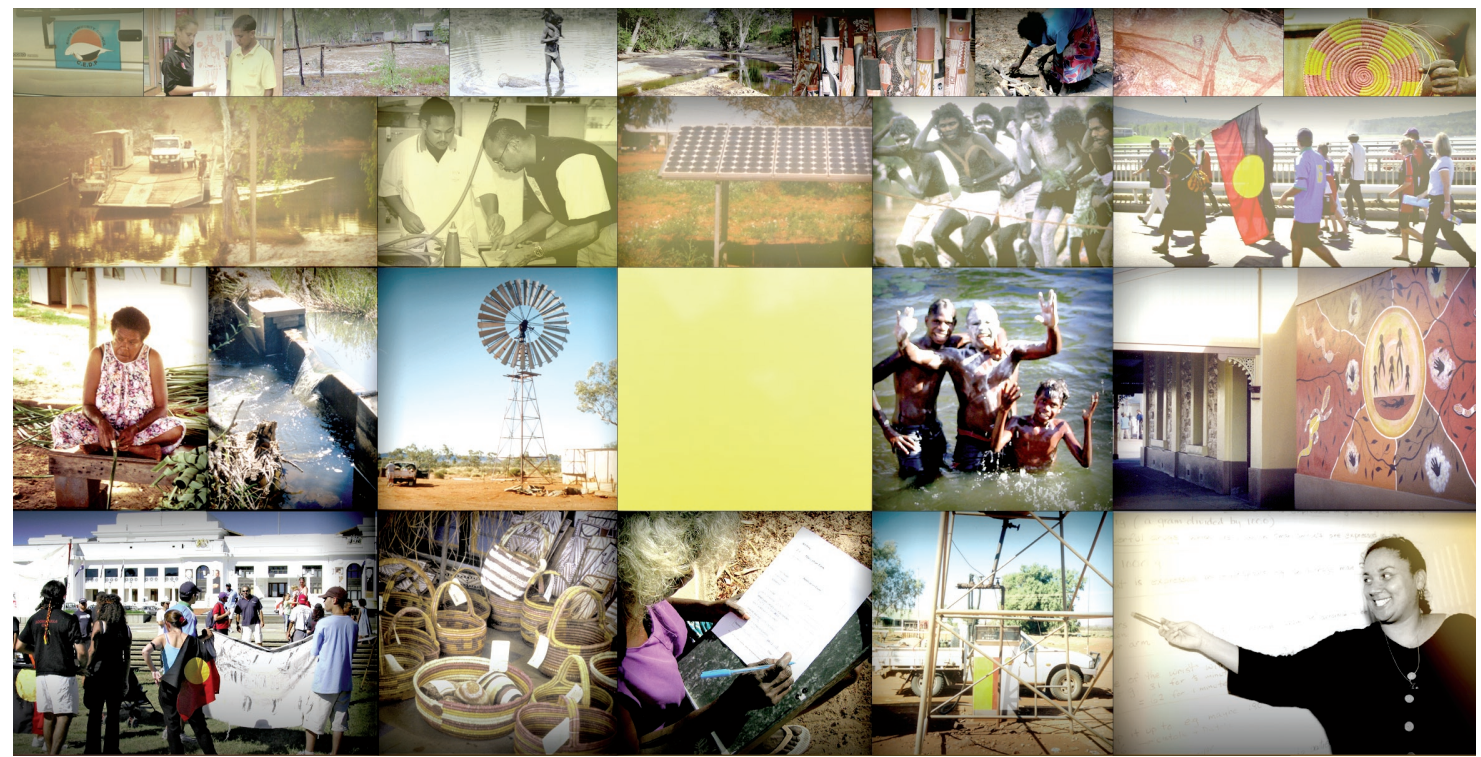

CENTRE

FOR ABORIGINAL ECONOMIC

POLICY RESEARCH 


\section{Series Note}

The Centre for Aboriginal Economic Policy Research (CAEPR) was established at The Australian National University (ANU) in April 1990. From 1990 to 2003 the Centre's main research partner was the Aboriginal and Torres Strait Islander Commission. Since 1 January 1999, CAEPR has operated as a University Centre and is currently funded from a variety of sources including the ANU, Australian Research Council, industry partners, and the Department of Family, Community Services and Indigenous Affairs.

CAEPR's principal objective is to undertake high-quality, independent research that will assist in furthering the social and economic development and empowerment of Aboriginal and Torres Strait Islander people throughout Australia. Its aim is to be a world-class centre undertaking research on Indigenous economic development issues that combines academic excellence with policy relevance and realism.

CAEPR is currently Australia's major dedicated research centre focusing on Indigenous economic and social policy from a national perspective. The Centre's publications, which include the CAEPR Discussion Paper series first established in 1991, aim to report on Indigenous circumstance, inform public debate, examine government policy, and influence policy formulation.

CAEPR Discussion Papers are intended as one forum for the dissemination of peer-reviewed research by Centre staff. These papers are produced both electronically and in hard copy.

Other CAEPR outputs include Research Monographs, Working Papers and Topical Issues. Copies of Discussion Papers, Working Papers and Topical Issues are available for free electronic download from CAEPR's website <www.anu.edu.au/caepr/>, while Research Monographs can be accessed via the ANU E Press website $<$ www.epress.anu.edu.au $>$.

Printed copies of publications can be purchased through the website or from:

The Centre for Aboriginal Economic Policy Research

Hanna Neumann Building \#21

The Australian National University

Canberra ACT 0200

Telephone 02-6125 8211

Facsimile 02-6125 9730

As with all CAEPR publications, the views expressed in this Discussion Paper are those of the author(s) and do not reflect any official CAEPR position.

Professor Jon Altman

Director, CAEPR

The Australian National University

February 2006

Cover page images courtesy of the Australian Institute of Aboriginal and Torres Strait Islander Studies and CAEPR staff members. 


\title{
BEING A GOOD SENIOR MANAGER IN INDIGENOUS COMMUNITY GOVERNANCE: WORKING WITH PUBLIC PURPOSE AND PRIVATE BENEFIT
}

\author{
W. SANDERS
}

No. 280/2006

ISSN 10361774

ISBN 0731556550

Will Sanders is a Fellow at the Centre for Aboriginal Economic Policy Research, The Australian National University. 



\section{CONTENTS}

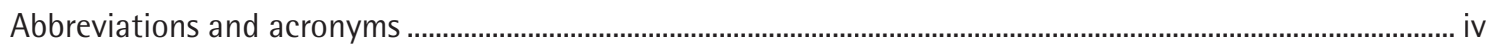

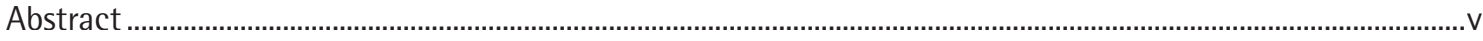

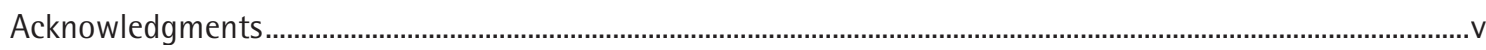

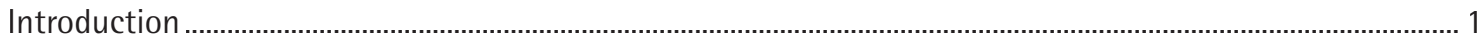

Being a boss in Pintupi settlements: the Folds analysis................................................................................ 2

Public purposes, private benefits and images of the Australian state ................................................................. 7

A realist view of being a good senior manager ...................................................................................................... 12

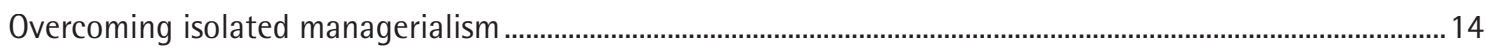

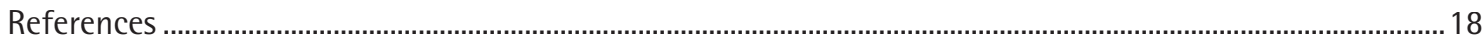




\section{ABBREVIATIONS AND ACRONYMS}

ANU

ARC

CAEPR

CDEP

CEO
The Australian National University

Australian Research Council

Centre for Aboriginal Economic Policy Research Community Development Employment Projects

Chief Executive Officer 


\section{ABSTRACT}

This paper seeks to understand the role of being a senior manager in Indigenous community governance, particularly though not exclusively in remote Aboriginal communities. It argues against the tendency of analysts and would-be reformers of Indigenous community governance to focus on the competence and ethical qualities of those who, from time to time occupy these roles, and asks instead how can isolated managerialism in Indigenous community governance be overcome?

The paper begins with Ralph Folds' analysis of relations between Pintupi settlements and the larger Australian polity. While taking much from Folds' analysis, the paper argues that he relies on too idealist a view of the Australian state and on a problematic distinction between the official and private uses of publicly allocated resources. The paper argues that the state's allocation of resources also inevitably involves a flow of private benefits and that public purposes and private benefits are not different phenomena, but rather different perspectives on state action. In light of this, the paper outlines a more thoroughly realist analysis of what it is to be a good senior manager in Indigenous community governance and then, in its concluding section, makes some suggestions for overcoming isolated managerialism.

\section{ACKNOWLEDGMENTS}

This paper has been developed as part of ARC Linkage Project LP0348744 with Reconciliation Australia on Indigenous community governance. Field work on which it is based has also been supported by the Governance Theme of the Desert Knowledge Cooperative Research Centre. Earlier versions of the paper were given as seminars at the North Australia Research Unit in Darwin and at the Centre for Aboriginal Economic Policy Research in Canberra. I thank participants at both those seminars for their useful comments. I also thank Geoff Buchanan, John Hughes and Frances Morphy for their assistance with final editing and layout. 



\section{INTRODUCTION}

I n 1999, the then Country Liberal Party Minister for Local Government in the Northern Territory, Loraine Braham, while introducing a reform agenda to the Legislative Assembly, noted that many community government councils in rural and remote areas 'face continuing difficulties in attracting sufficient numbers of qualified, competent and ethical staff', and that many 'fail to do so'. 'At any given time', she continued, 'at least 10' of these councils in the Northern Territory 'are in significant financial or managerial difficulty' (Braham 1999: 3). In 2002, the then Labor Minister, John Ah Kit, went somewhat further, claiming that it was 'almost impossible to find a functional Aboriginal community anywhere in the Northern Territory'. In attempting to explain the apparent failure 'to build effective local government on Aboriginal communities', he also noted that 'skilled and dedicated council staff' are 'extremely difficult to recruit and retain ... in remote centres'. He continued by referring to the 'other side of the coin': that 'there have been any number of incompetent or crooked people working for Aboriginal communities' (Ah Kit 2002: 7). While not wanting to be disrespectful to either of these ministers, I do want in this paper to call into question the emphasis placed in recent years on incompetent and unethical staff as an explanation for limited success in Indigenous community governance.

In a recent paper, focused mainly on debates about greater regionalism in Northern Territory local government, I ended by noting that senior managerial staff in remote area Indigenous community governance organisations tend to come under 'considerable community pressure over the allocation of resources' and also to be isolated from peer support and supervision. In these circumstances of 'isolated managerialism', I argued, it is likely that senior managerial staff are 'not so much unethical or incompetent at the start of the task, but rather become somewhat jaded and dissatisfied during its course', often then leaving the organisation at a point of tension over the allocation of resources without managerial succession having been properly put in place. Indeed, in some instances, I noted, the administration of small Indigenous community government organisations can fall into complete disarray with the abrupt departure of senior managerial staff, before 'the whole rather inadequate cycle of isolated managerialism' starts all over again (Sanders forthcoming; see also Sanders 2004: 11).

In this paper I want to take this analysis of isolated managerialism somewhat further by asking what it takes to be a 'good' senior manager in an Indigenous community governance organisation. My focus is primarily, though not exclusively, on remote area organisations, and I will begin by considering Ralph Folds' analysis of relationships between Pintupi settlements and the larger Australian polity (Folds 2001). Building on Folds' analysis of what it means to be an institutional boss in such settlements, I will argue that senior managers in Indigenous community governance have to work with both public purpose and private benefit, and that these are not different phenomena, but rather different perspectives on the allocation of resources. I will also argue that, while there are differences of worldview across the sociocultural interface in remote Indigenous settlements, Folds somewhat overstates his case due to a rather one-dimensional and idealist view of the Australian state. Folds' analysis is, however, still a good foundation for outlining a realist view of 
being a good senior manager in Indigenous community governance, which is the subject of the next section of the paper. In the final section, I argue that rather than rushing to make judgments about how good or bad particular senior managers are, analysts and reformers should be focused instead on how to overcome isolated managerialism in Indigenous community governance.

\section{BEING A BOSS IN PINTUPI SETTLEMENTS: THE FOLDS ANALYSIS}

After an initial historical description of contact between the Pintupi and the settler society, Folds begins his analysis of 'the contemporary interface' by referring to his own personal experience as the school principal at Walungurru over more than a decade. He notes that the 'dominant society' views this role as 'the bearer of important social justice values' but that Pintupi dismiss such 'institutional managers' as mere 'bosses for paper.' Quoting the anthropologist Fred Myers, Folds explains that the authority of bosses in Pintupi society is 'sustained by generosity in providing access to valued resources ("looking after") rather than [through] withholding them for the greater public good' (Folds 2001: 40). Institutional managers who withhold resources from Pintupi 'in order to fulfil their official purpose' are considered 'hard' bosses who are 'careless of relationships through their unreasonable greed' (Folds 2001: 41).

Returning later to this idea, Folds explains as follows:

In declaring whitefellas 'paper bosses', Pintupi are saying they have no inherent power over them. For Pintupi the context of power is personal; their view is that a boss must first develop a relationship with them, after which work is negotiated within that relationship. A boss who slashes his workers' pay merely because they have not attended to all their duties is considered to care very little for the relationship, and perhaps to be unworthy of being a boss for them at all. As Myers puts it, 'Hierarchy ... exposed as non-nurturant [is] rejected (Folds 2001: 51).

Folds also notes that whitefella bosses who are 'too directive' are referred to as ramarama or 'cheeky' by Pintupi, which suggests another form of hardness alongside the withholding of resources.

Folds places this description of being a whitefella boss in a Pintupi settlement in a larger context of Pintupi values, economy and views of government or the state. The highest value of Pintupi life, he argues, is building relationships with walytja, meaning family or kin. This is done through an economy in which acquired resources are heavily used and quickly consumed, rather than in any sense preserved. 'Value is expressed through use, rather than hoarding' (Folds 2001: 70). Money is disposed of quickly, even when it arrives in unusually large quantities as a 'windfall' (Folds 2001: 75). While 'reliance on relatives' through 'reciprocal claims' on their acquired resources, far from being a 'problem', is 'the life-blood of both the family and the economic system' (Folds 2001: 76). Folds argues that Pintupi have a 'patron-client' view of government, or the state, similar to that of 'seniors' in traditional life. Both 'hold' or 'look after' people 'in a material sense' and in so doing build their moral authority (Folds 2001: 42). This view of the state takes us back to 
the role of whitefella institutional bosses in Pintupi settlements, who are the primary local manifestation of government and who, as Folds notes, are 'held accountable on both sides' of this relationship between Pintupi and the state (Folds 2001: 41).

Folds also argues that the 'Pintupi economy is antithetical to much that western society holds sacred' and that because of this 'the dominant society mistakenly assumes that the absence of a Pintupi impetus towards material accumulation is indicative of a deep malaise' (Folds 2001: 76). He notes a major tension between Pintupi commitments to walytja and a state-based non-Indigenous project of pursuing 'material equality' through programs aimed at overcoming the disadvantage of particular 'common-interest groups', such as women, children, the old or the sick, in the name of 'social justice'. He writes:

The social justice ideal of material equality, confidently proclaimed as compatible with indigenous selfdetermination, is actually being constantly overridden by the resilient cultural difference in what Pintupi consider responsible behaviour. When this happens, the lack of accountability is seen by mainstream bureaucracies to lie on the indigenous side. However, while the values of shared identity and walytja create obvious difficulties for material prosperity, this is an outcome that represents a different logic of responsibility, not a lack of it (Folds 2001: 73-4).

Then later he writes:

Bureaucracies do not accept for a moment that particular groups chosen by Pintupi should be able to prioritise their access to resources ahead of the groups they (the bureaucrats) have chosen, such as the sick, women, children, the old or outstation residents (Folds 2001: 83).

Folds' work is largely dedicated to exploring these ideas of fundamental tension and antithesis between state-based and Pintupi worldviews. He proceeds by an accumulation of stories about intervention programs which did not work out as intended by their state-based, social-justice-inspired designers, but which nonetheless Pintupi valued as a source of resources and which they incorporated into their own walytjabased system of economy and society.

For example, Folds tells the story of a four-wheel-drive vehicle given under a Commonwealth Government program to the women of Walungurru 'to empower them as a group'. He writes:

This sudden channelling of government resources fuelled the expansion of women's interests. These were strengthened by the role of whitefellas who supported what they saw as the women's interests against the men who, Pintupi women indignantly explained, were always greedy for anything they had (Folds 2001:95).

Folds goes on to explain that 'newly acquired settlement resources' are often initially used for their 'intended purposes ... out of deference to the government bosses who provide them', but that 'claims are quickly 
staked' for uses which, perhaps to western eyes, push at the margins of these purposes and that, once permitted, establish precedents or even rights for further use. When a relative of one of the women died in a 'distant settlement' the women's truck was used for travel to 'sorry business' and to bring home the granddaughter of another woman who 'held' the truck. Folds writes:

Although the whitefellas had been wary of this 'private' use, the women who asked for the truck pointed out that it was, after all, not the whitefella's personal property. The husband of one of the Pintupi women did the driving, thus establishing precedents for both 'private' use and male drivers. This was not lost on other men or relatives (Folds 2001: 96).

The women's vehicle was soon travelling to 'sorry business' regularly and being used to pick up children and do many other things. Its use was even 'demanded' on such insubstantial grounds as 'an old woman might need a lift home'. An attempt by the whitefella boss for the truck to put in place 'strong rules' for its use was summarised by Folds as follows:

Decisions along these lines were forcefully endorsed by Pintupi women when they met as an exclusive group and they seemed binding enough at the time, but outside the meetings the rules were instantly discarded. The rules were summed up by one woman as 'not helping anyone', and shameful edicts were quickly reversed or ignored in the face of demands from walytja. Ultimately, Pintupi could only make decisions based on relationships, not the official purposes based on a collective of women (Folds 2001: 96).

In light of these demands and the reversal or ignoring of the rules, the whitefella boss for the women's truck 'complained bitterly that she felt little support' or 'public backup from the women'. If she enforced the rules and withheld the keys, she was accused of being 'cheeky' or 'holding wrong way'. When she gave in, use of the truck was heavy and varied. Soon the truck was damaged during use by men on 'travelling ceremonies' and the whitefella boss was 'roundly criticised by the women, who claimed she should not have given in to the men', but who had found it 'impossible' themselves to refuse the men's request. The exasperated whitefella manager now relinquished any claim to being 'boss' for the truck, but was severely criticised in doing so for 'not helping'. Folds continues:

The status of the vehicle, as owned by any individual or group, now became nebulous and a series of public fights over its use erupted until it was vandalised during a fight and removed to the settlement garage. Some Pintupi said it should be burned. A vehicle that had been fiercely fought over was suddenly ignored, with many Pintupi expressing satisfaction that it had been immobilised since that stopped the incessant fighting (Folds 2001: 97)

This story tells us much about being a senior manager in an Indigenous community organisation, particularly in remote areas. But it is not this which Folds wants to emphasise and analyse at the end of his telling of the story. His primary concerns are the difference of worldviews between the state-based officials focused on 
disadvantaged common-interest groups and the Pintupi focused on walytja and the way in which resources offered under the former worldview are integrated, during their use, into the Pintupi worldview. He writes:

A material resource offered in the quest for 'social justice' for a particular group is appropriated by Pintupi society, rather than changing it in the way intended. Targeting of disadvantage based on alien common-interest groups reinforces a view of government as an unfathomable and unpredictable boss, but since it provides opportunities for Pintupi to meet their own agenda they do not argue. While their options have been restricted to seizing these varied, apparently arbitrary, opportunities as they come along, they do not jeopardise their own enduring relationships with walytja in the process (Folds 2001: 97).

When, in the light of this story and others, Folds does return specifically to the issue of being a whitefella managerial boss in a Pintupi settlement, he focuses interestingly on the ideas of corruption and accountability. He writes:

In Pintupi terms, a boss is in debt to those he has to deny and to the employees he directs ... The settling of debt incurred by a boss to employees may well lead to pressure for corruption in western terms, because bosses may be compelled to support Pintupi activities by allowing non-official and inequitable use of resources.

Bosses are simultaneously held accountable to the funding agencies they represent, and from whom they obtain the money needed to keep institutions running and, in a far more immediate sense, to Pintupi, who are themselves in no way accountable to those agencies and have a completely different worldview from them. Bosses are always vulnerable to accusations of corruption from the institution they are managing, the 'community' they are serving, and the wider society to whom they are ultimately accountable, groups whose understanding of the term can be oppositional (Folds 2001: 148).

Folds sees these frequent accusations of corruption as the product of the different worldviews operating on the different sides of the 'settlement/institutional interface', rather than being a particular reflection on the competence or the ethical qualities of the individuals occupying the whitefella boss roles in the settlements. He acknowledges that these accusations of corruption place 'enormous stress' on the individuals at the interface and this reinforces one of his earlier points that:

Western institutions on Pintupi settlements are not comfortable places to be, as evidenced by the generally rapid turnover of their whitefella administrators (Folds 2001: 60).

Folds also addresses the issue of why Pintupi are often reluctant to take on these senior managerial roles in Indigenous community governance organisations, despite often having the literacy and other skills to do so. He writes:

An institutional boss is responsible for many people regardless of relationship, a role Pintupi-already fully obligated to relatives-regard as an acute form of punishment ... 
Being responsible for, and to, non-relatives arouses heated complaints from one's own kin. When a man was asked why he only took his own walytja in his (institutional) Toyota, he explained, 'If I take others my walytja get angry with me'. To deny institutional resources to one's own family makes Pintupi susceptible to the accusation of being 'too hard' (lacking compassion), as they are placed in the dangerous position of being expected to deny rightful claims from relatives in favour of institutional imperatives (Folds 2001: 148).

Folds sees Pintupi as having worked out a 'volatile, yet usually workable, compromise' in which they 'retain control over the direction of settlement institutions' but employ 'outsiders as 'bosses', to accept final responsibility for their day to day operation' (Folds 2001: 149).

On the issue of how the mainly non-Indigenous people who occupy managerial roles in Pintupi settlements should go about their task, Folds offers the following fragmentary insight and advice. He writes:

Whitefella bosses are not assigned authority by virtue of their positions. Nevertheless, they can choose to insist that they stand outside the relationship system and cling to the illusory authority they assume they bring with them to the settlement. Following this path they will be relentlessly informed of their obligations, told they are mad and publicly criticised for shortfalls that seem to them far removed from their official role, because bosses are considered to have infinite responsibility ...

The value Pintupi place on their relationships with their bosses cannot be discounted for long, and since it is through those relationships that authority is expressed and institutional work done, it is selfdefeating to try to do so. That I would 'hold' Pintupi in my 'employ' while I worked for the community was not negotiable, although how I did so was open to debate (Folds 2001: 153).

This is clearly counsel to whitefella bosses to work with the Pintupi emphasis on relationships and walytja rather than thinking they have some other source of authority. But it is not counsel simply to abandon other accountabilities in favour of that to Pintupi and their worldview. Folds writes early in his account that as school principal he did not just allow his Pintupi workers the 'autonomy' to pursue their own interests, as they saw them, and that in his 'recalcitrant clinging to western accountabilities' he was often a 'sad disappointment to them' (Folds 2001: 52). Folds' advice to senior managers seems, therefore, to be to strategically balance the different accountabilities to which they are subject from the different worldviews on the different sides of the settlement interface, rather than to abandon any one form of accountability in favour of another.

This idea of senior managers in Indigenous community governance strategically balancing different accountabilities is quite helpful, but Folds does not give us the tools to take the analysis very far. How can one strategically manage or balance accountabilities which are coming from antithetical worldviews on the different sides of the settlement interface? Here I want to suggest that Folds has overdrawn the difference between those worldviews, not by taking issue with anything he says about Pintupi, but rather by taking issue with his images of the Australian state and his distinction between the public or official purposes of state programs and the potential private uses, or benefits, of resources that flow from them. 


\section{PUBLIC PURPOSES, PRIVATE BENEFITS AND IMAGES OF THE AUSTRALIAN STATE}

At the beginning of his women's truck story, Folds identifies the use of the truck to attend a funeral as 'private', though he also chooses to place the word in quotation marks. Throughout the passages above quoted from Folds, such private use is contrasted with 'official' purposes or use, as if this were a reasonably clear and useful distinction. I want to suggest that while this distinction may seem useful in principle, it is in practice very hard to make and far from clear. I want to suggest this lack of clarity by asking in what way was using this truck to go to a funeral a private use and not a public or official one? Recall that this truck was given to the women of Walungurru to empower them and to enhance their interests. So what did those who gave the truck to the women think it would be used for if not to attend funerals and to pick up and deliver people to and from distant settlements for various reasons-to run a sort of on-demand public transport system for Indigenous women and those close to them? It seems to me that there was in fact nothing particularly unofficial, or outside the public purpose, in this use. Rather the problem was simply one of heavy demand for a very valued and scarce resource, which saw it consumed not only very quickly and somewhat unequally, but also in the end somewhat acrimoniously.

Perhaps what 'public' or 'official' use might mean in this instance is simply restricted use; just within the settlement, within office hours, running women to and fro between their houses, the shop, the health centre and other centres of daily activity within the settlement, and perhaps also just driven by two or three authorised people, such as the whitefella boss for the women's truck and one or two designated Indigenous women. But in what way would this be empowering the women of Walungurru as a more numerous group? And how could this restricted use pattern be defended against the accusation of hardness and not helping in the face of unmet need?

My own vehicle story from Walungurru comes from 2001 when I worked there for a single week investigating interest in being part of the Community Development Employment Projects (CDEP) scheme, a type of workfor-the-dole arrangement which has been offered to increasing numbers of remote Indigenous settlements and other Indigenous communities since the late 1970s (Sanders 1988, 2001). As I was preparing to leave Walungurru after my week there, I was asked by one of the councillors with whom I had been working whether I could give him a lift to a settlement a couple of hundred kilometres away where there was a sports carnival that weekend. Naturally I said yes, and during the trip I was told how the Chief Executive Officer (CEO) of Walungurru Council restricted use of council vehicles for taking people to sports carnivals, usually to just one bus mainly for the competing teams. The councillor suggested that other council vehicles should also be made available for people like himself to attend and support the teams. Resisting the temptation to simply agree, (thereby implicitly criticising as 'too hard' the CEO with whom I had also just been working and also installing myself in some more enlightened and generous moral position of sympathetic softy), I sympathised with the difficulty of the task of deciding how many council vehicles should be allowed to be used for attending sports weekends and who should have priority in travelling in them. Jokingly, seeing this 
councillor was both quite old and had a badly injured leg, I suggested that he offer himself as the football team manager, which might in turn help secure him a place in the bus. This was accepted in the tenor in which it was offered, and our conversation soon turned to other things. However, after I had dropped the councillor at the sports carnival and was continuing on my way, I continued to reflect on the difficulty of distinguishing between public purposes and private benefits in the use of Walungurru Council resources.

Taking teams, particularly of young people, to sports carnivals is a public purpose to which most of us could quite easily relate. Taking spectators to sports carnivals or mourners to funerals might seem, in the larger Australian society, to be regarded as essentially private matters. But this is in circumstances of considerably more private affluence and it is hard to say why, in other circumstances, these should not also be seen as worthwhile public purposes. This is particularly so if, in directing resources to Indigenous community organisations, governments are also promoting ideas such as community self-empowerment and selfdetermination. Who better, under these philosophies, to decide on the precise nature of public purposes in Indigenous communities than Indigenous people themselves? Allowing Indigenous people in remote communities to make these decisions will probably lead to broad definitions of public purposes, and hence to heavy demands on Council resources, which will, in turn, be consumed very quickly. But this is not to say that these broadly-defined purposes are not legitimate and public. What appears to be being offended here is simply western sensibilities about how quickly resources like vehicles should be consumed. Within the western social world a vehicle is consumed within perhaps five to fifteen years, and somehow more rapid consumption with one or two years seems unacceptable.

On the issue of vehicles in Indigenous community governance, I could also tell the story of an Indigenous community government CEO who went to his council seeking clarification and prioritisation of the use of council vehicles. Being open to the need to support activities in the community beyond those directly involved in council employment, he suggested that attending funerals and sports carnivals was a permissible use, but that council policy should be that it is a lower priority than the business of council employees and of employment matters in the community more generally. The council however, disagreed, installing funerals as the highest priority and leaving the CEO with a policy which would, no doubt, be questioned by the various funders of council vehicles. This CEO's task of strategically balancing different accountabilities was clearly not going to be easy.

Stories about demands on vehicles abound in Indigenous community governance, as access to transport is clearly both a highly valued and a very scarce resource, particularly in remote Indigenous communities. One insightful line of commentary and questioning, which emerged when I first gave this paper as a seminar in Darwin, was whether there would be anything like the same level of demand and potential for disputation if the resources being offered by a social-justice-inspired state program were jobs or buildings. Another line of commentary was that only a Commonwealth department which had had little historical involvement in 
this area would offer vehicles in such a naïve and potentially fraught way as the women's truck story implies. The Northern Territory Government, it was suggested, had learnt from greater exposure and past experience not to offer vehicles in such a manner. While these are both useful lines of commentary, it does seem to me that there is still a general problem here which cannot be avoided.

The problem is that when the state devises programs and commits resources aimed at public purposes and involves Indigenous community organisations in the pursuit of those purposes, people working in these Indigenous community organisations cannot usually avoid also allocating private benefits while pursuing these public purposes. True there are public goods like roads, parks, rubbish runs and electricity and water supply systems which Indigenous community councils can provide without getting too intimately involved in processes of distributing resources to individuals. However, if this was all that Indigenous community councils did, they would probably not be seen as doing enough for their constituents. Further, even were councils to restrict themselves to the provision of these more public goods, there would still be the issue of who gets the job grading the road, or on the garbage run, or attending to the electricity and water supply infrastructure, and to what extent having these jobs also means better access to vehicles and houses in comparison to other community members. Access to jobs, vehicles and houses are all private benefits derived in the course of the state pursuing public purposes in conjunction with Indigenous community councils and there is, quite simply, no other way in which the state, and the community councils, can act.

Hence public purposes and private benefits are not different ways in which the state can commit resources, but rather different perspectives on the same state action: the allocation of public resources. A job given to person $x$ can be defended as an appropriate pursuit of public purpose $y_{1}$ on the grounds of merit, technical competence, requisite local knowledge, or some other pre-specified criteria. A house allocated to person or family $z$ can be defended as an appropriate way of addressing outstanding housing need in the community. But these very same actions can also be seen as favouritism towards that person in comparison to other persons who also have claims to either that competence or need. And the senior managers who are seen as having ultimate responsibility for these allocative decisions will, no doubt, be accused of favouritism, nepotism, incompetence and even corruption. They can, of course, anticipate and attempt to lessen such accusations by laying down decision criteria beforehand and putting decision processes out in public. But this will still not stop some people from adopting a private benefits perspective on those decisions, rather than a public purposes one.

Barry Hindess makes a closely related point in his recent review of corruption and Australian public life more generally. He argues that disagreements about corruption reflect 'competing understandings of the public interest and the proper purpose of government' and are part of 'the normal condition of politics' (Hindess 2004: vii-viii). Those close to decision-making processes in any area of public life may take a somewhat more 'relaxed view of what is acceptable' than those who are more distant, suggesting that their mode of 
operation is simply what it takes to get things done in this area (Hindess 2004: viii). However, those more distant from the circumstances and events of particular decision contexts will want to push for the relevance and upholding of more general decision-making principles and may accuse those close to the processes of going too far in their 'whatever it takes' attitudes. ${ }^{1}$ Hence, like all people who become involved in public life and public decision-making processes, senior managers in Indigenous communities should expect accusations of maladministration and incompetence, or even corruption, and should be prepared to weather and to manage such accusations.

Senior managers involved in Indigenous community governance are not, in that sense, the exceptions of Australian public life, but rather part of its rule. Nor, for that matter, are the two Northern Territory Government ministers with whose words we began exceptional, as they accused others in somewhat different positions in public life to themselves of incompetence or corruption. Things always look different from different positions within the structures of public life, as people debate and pursue public purposes and the public interest while at the same time deriving private benefits.

Perhaps another way to make this point about public purposes and private benefits is to argue that Folds' analysis relies on an image of the state that is too idealist and one-dimensional, while his analysis of Pintupi settlements is much more realist, contextual and concerned with material resources. While the state does, as Folds contends, articulate the ideal of achieving material equality between different common-interest groups in the name of social justice, it also articulates many other competing ideals, such as encouraging economic development, rewarding individual and corporate initiative, providing scope for choice and supporting families. So how does the social justice and material equality ideal relate to these other ideals, which may at times seem to push in other directions? Beyond these competing ideals there is also the question of what the state does, more materially, and how this is understood by the citizenry. One of the earliest and most quoted realist characterisations of the Australian state was Hancock's idea, dating from 1930, that:

Australian democracy has come to look upon the State as a vast public utility, whose duty is to provide the greatest happiness to the greatest number ... collective power at the service of individualistic 'rights' (Hancock 1961: 55).

In reminding us of this characterisation over fifty years later, Galligan argued that it was somewhat 'exaggerated' and incomplete, but not that it was wrong. Indeed he wanted to build on Hancock's analysis in encouraging Australian political science away from a narrow focus on political institutions and processes towards more political economy, with a focus on both the corporate and the individual private benefits emerging from political processes (Galligan 1984). This more realist image of the Australian state resonates with Folds' portrayal of Pintupi understandings of governments which, like seniors in Pintupi society, build their moral authority through materially looking after people. So perhaps Pintupi and other Australians

1. The 'whatever it takes' phrase was, of course, made famous in Australian politics in the late 1990s as the title of the autobiography of former Labor power broker and minister, Graham Richardson. 
view government, or the state, quite similarly if we focus in both instances on realist or materialist views of political processes rather than in one instance on realist views and in the other on more idealist views.

This mixing of idealist and realist views may also be true in relation to Folds' economic analysis. Recall that Folds' saw the Pintupi emphasis on current resource use as 'antithetical' to a 'sacred' western emphasis on resource hoarding and accumulation. While it seems to me that western economic ideals do emphasise hoarding rather than heavy current use of resources, economic value does ultimately inhere in use and so western economic practice involves much more balancing of current use and hoarding than the ideal suggests. Also it is not clear to me that western ideals for state economic practices are quite the same as for private economic practice. Do good state managers hoard resources, or do they spend their budgets fully, or perhaps even overspend them a little, in order to demonstrate that they are pursuing public purposes for which there is considerable demand or need, while also being reasonably fiscally responsible? I suspect they do more of the latter than the former.

Hence if we adopt a more realist image of both the Australian state and of western economic practice, as well as of Pintupi lifeways and worldviews, we can argue that Folds has somewhat overdrawn the differences across the settlement interface. My point here is not to argue that there are not real and substantial differences of lifeways and worldviews across the Indigenous settlement interface. Like Folds, I believe there are. I also believe that Folds analysis is insightful not only in relation to Pintupi but also in relation to other Indigenous people, at least in remote areas. David Martin's work on Indigenous culture and economy in Cape York makes similar points about the intensive use, rather than hoarding, of resources and it also draws on a more general literature on 'demand sharing' in Australian Indigenous societies (Martin 1995). My point is simply to argue that Folds has somewhat overdrawn the idea of difference in worldviews across the settlement interface and that we can understand many of the phenomena that he observes at that interface without having to resort to an explanation based so heavily on different worldviews.

My more minimalist explanation would argue that there are always tensions and accusations of incompetence and corruption in public life as public purposes are pursued and as the resources devoted to those purposes inevitably become used in ways which also bring private benefits to particular individuals, families and corporations. What we observe at the remote settlement interface in Indigenous community governance is not totally different from what we might observe in other, more mainstream local government, or in public life more generally, as the pursuit of public purposes also produces a flow of private benefits. 


\section{A REALIST VIEW OF BEING A GOOD SENIOR MANAGER}

So where does this more thoroughly realist analysis take us in relation to being a good senior manager in Indigenous community governance? First and foremost, it tells us that the job of senior managers in Indigenous community governance is about getting resources out to Indigenous people. This material reality should be acknowledged and embraced, rather than denied or embarrassingly conceded in deference to some more idealist view of the Australian state or Indigenous community processes. Behind every idealist image of the Australian state or Indigenous community processes there is still a material reality of the allocation of public resources.

Second, we should acknowledge that allocated public resources will probably be quite heavily used and therefore also, in many instances, quite quickly consumed. Senior managers should not expect great support among Indigenous representatives or constituents for rules and practices which hoard resources on the basis of narrow definitions of public purpose or in anticipation of some leaner public policy future. The predominant pressure and political dynamic will be to use available resources quite quickly to meet pressing needs in Indigenous communities. Indeed while being fiscally responsible within existing budgets, senior managers in Indigenous communities should not become too greatly concerned with hoarding resources. This is more a private, western economic ideal than a public economic practice, where full spending of budgets is the norm and a part of ongoing budgetary claim-making. Senior managers will probably be more greatly appreciated and rewarded, both by government funders and by Indigenous constituents, if they keep resources flowing to community members and also seek out ways of sustainably expanding total resource flows.

Third, within whatever level of resource flows they have, senior managers in Indigenous community governance should expect pressures for concentration and unevenness in the distribution of these resources, as much as for widespread, even distribution. Some degree of unevenness in the distribution of resources is perhaps inevitable, particularly with large, less-easily-divisible resources like jobs, houses and pieces of physical infrastructure. Also uneven distribution of resources to particular places, families and individuals is not in itself necessarily a bad thing, but it will need to be defended in terms of the public purposes it serves. Indeed any distribution of resources-however even or uneven-between Indigenous places, families and individuals will need to be defended in terms of the public purposes it serves, both to the community being served and to the funders of various programs.

Hence a fourth finding of the analysis is that the defence of resource distributions in the language of public purposes is a major part of the senior manager's job. To treat such defence as somehow secondary to, or less important than the actual distribution of resources would be a major mistake. Defending actual material distributions in the language of public purposes is what strategically balancing different accountabilities and perceptions is largely about. 
The converse of this fourth point is that any material distribution of resources can also be interpreted as unfair or inappropriate and as not fulfilling public purposes. So a fifth finding is that senior managers should expect to be accused of unfairness, incompetence and even corruption quite frequently in the course of their jobs, both by Indigenous constituents and by funding bodies. Accusations may be somewhat fewer if senior managers have paid attention to and actively managed perceptions of resource distributions, but they will never go away entirely. The best defence against such accusations is conventional good governance: being open and transparent about council and senior managerial decision making, and putting out to the public realm as much as possible of the processes and thinking that goes into making decisions. This will make allegations of incompetence and corruption harder to sustain in the light of public evidence, but it will not make them go away.

A sixth finding, arising from the above, is that the skills of being a good senior manager in Indigenous community governance are as much political and strategic as they are technical, financial or administrative. Good senior managers need a clear strategic understanding of the circumstances and interests pushing in on them, and a sense of how to balance and accommodate their differing requirements and demands while still keeping the resources flowing out to Indigenous people. Good technical, financial or administrative skills are clearly a bonus, but they won't be enough without some broader, quite political, strategic understandings and abilities. Indeed, technical skills, such as in finances, can conceivably be 'bought in' by senior managers in Indigenous community governance from other organisations like accounting firms, but a strategic sense of the circumstances in which they operate would seem almost impossible to outsource.

Seventh, I want to return to one of Folds' points which, like his difference of worldviews across the settlement interface, is perhaps a little overstated, but still has some cogency and merit. This is the point that we should not necessarily expect local Indigenous people always to be keen to take on these senior managerial roles in Indigenous community governance, even when they have the necessary technical skills, such as literacy and numeracy, and have shown leadership tendencies among their social peers. These jobs are very tough assignments, both strategically (in terms of the balancing of diverse interests and accountabilities) and personally (in terms weathering the inevitable accusations of misconduct and corruption). Many local Indigenous people, like many non-Indigenous people, simply will not wish to take them on. And even those who do may look to people from outside their local family networks to take ultimate responsibility for any particularly 'hard' decisions which restrict people's access to resources or which strongly direct other people's behaviour.

I note, in relation to these last two points, that John Ah Kit, the Indigenous, Northern Territory, Labor Party Minister with whose words I began, had a successful career as a senior manager in a number of Indigenous community organisations before entering the Legislative Assembly in 1995. Also, one of Labor's 2005 additions to its Northern Territory Legislative Assembly team, Alison Anderson, is another example of an Indigenous person with a successful managerial career in Indigenous community governance organisations. She was the CEO of Papunya Aboriginal Community Council for a decade and a half before becoming a Commissioner of the Aboriginal and Torres Strait Islander Commission in early 2000. Hence, somewhat 
qualifying Folds' analysis on this point, there are Indigenous people who are willing to take on these senior managerial roles in Indigenous community governance, and who can use them to launch larger-scale political careers. But both Anderson and Ah Kit, it seems to me, illustrate the importance and primacy of having strategic political skills to survive and flourish in these roles. From observation of their careers, I would argue that both have these strategic political skills in abundance and have relied on others around them for technical, administrative or financial expertise.

In summary, I want to argue just two things in relation to the practical realities of being a senior manager in Indigenous community governance. The first is that this is a very tough job, with different expectations, perceptions and accountabilities pushing in on it from different sides. In this environment, just surviving in the job for a few years and leaving in an orderly fashion can be quite an achievement in itself. The second is that if, in our analysis of how and why things go wrong in Indigenous community governance, we focus on the competence and ethical qualities of particular individuals who at various times occupy these key managerial roles, then we will miss the opportunity to see that it is the isolation of these managerial roles which is the more pressing and fundamental problem. I want to conclude therefore, by returning to the idea of isolated managerialism and how to overcome it.

\section{OVERCOMING ISOLATED MANAGERIALISM}

I will begin this final section with another story about being a senior manager in Indigenous community governance which, to my mind, illustrates both the difficulty of the job and also of making judgments about the goodness of senior managers, whether in terms of competence or ethical standards. I want to argue that, rather than being focused on these issues, analysts and would-be-reformers of Indigenous community governance should be focused more on overcoming isolated managerialism. The story also, incidentally, illustrates once again some of the potential pitfalls of greater regionalism in Indigenous community governance.

My story dates from a decade ago, and relates to one of the earliest instances of adopting a regional approach to Indigenous community governance in the Northern Territory. Ten small localities were encouraged to come together as a single council, with each locality having two council members. Soon after the council's formation the issue arose of how councillors were to get to the monthly meeting, as some of them had almost 200 kilometres to travel. The CEO of the time worked out that the council could lease a vehicle for each of the outlying council wards, which the councillors could use both to get to meetings and to attend to constituency matters in between times. All went well, until it became evident that the vehicles were doing far more kilometres than was allowed for under the terms of the leases and that, because of this, not only were there additional running costs but also some lease penalty clauses kicked in. After three years, as the leases were coming to an end, there was also the issue of whether the condition of the vehicles met the terms of the leases, and if not what penalties might again apply. The council was, at the end of the three-year leasing period, facing a financial overrun relating to the vehicles of the order of a couple of 
hundred thousand dollars. The CEO chose at this time to terminate his employment with the council, leaving his deputy to bring in the leased vehicles from the councillors, deal with the financial overrun and inform the councillors that in the future they would not be able to have vehicles on the same basis as they had in the past. This was not an easy process and, within a year, the deputy had also terminated his employment with the council.

A decade later, I can report that this CEO is still remembered among councillors as someone who was 'good' and could deliver resources. Others with a more financially-informed, external perspective, including myself, might judge him somewhat differently. But it is not clear to me that he can be simply judged as 'bad', or incompetent or corrupt. Positively, he was innovative and entrepreneurial in his use of vehicle leasing as a way of responding to the legitimate concerns of councillors. Perhaps he was somewhat naïve about the level of vehicle use that would ensue. Or perhaps, if he was more knowing, then he was somewhat unstrategic if he saw his future with the council lasting any longer than the terms of the vehicle leases.

All these judgments about this person's competence and ethical standing could be thrown around and debated. But the one thing that seems to me very clear is that this senior manager was, systemically, very isolated. Where was the learning from the past about the pitfalls of leasing vehicles under standard government arrangements for use in Indigenous community governance? Where were the system supports and supervisory structures which could or should have brought these pitfalls to this CEO's attention? Where was the career structure with horizons beyond the life of these leases which might have made this CEO think twice about the reasonably anticipatable consequences of the decision to lease these vehicles? None of these structures and processes seemed to be in place. This CEO, in a new, larger, regional community government in the Northern Territory was as much on his own, unguided and unsupervised, as his counterpart in a smaller more localised community government. Indeed regionalism was, ironically, part of the source of his problems, as it gave legitimacy to the demands of councillors for vehicles, in that they needed to attend monthly meetings away from their home communities.

I do not wish, here, to be overly critical of the push towards regionalism in Indigenous community governance in the Northern Territory. As suggested in my earlier paper (Sanders 2004), my aim, if this is possible, is to be both critical and supportive of this regionalism push. But greater regionalism alone will only marginally reduce the organisational and career isolation of senior managers in Indigenous community governance organisations. These will still be small organisations with only a few managerial staff. So it is links beyond the individual Indigenous community governance organisation which must be developed and come into play if isolated managerialism is to be more fully overcome.

The most obvious external people to be supporting, and in the process also mutually checking, these isolated managers in Indigenous community governance are the managers of funding programs in higherlevel government agencies. These program managers in higher-level government organisations need, in the first instance at least, to see their job as supporting and assisting senior managers in Indigenous community governance, rather than standing distant from them or assuming, at the outset, that they will be 
incompetent or corrupt. They need to show empathy and understanding for the difficult strategic balancing of accountabilities in which senior managers in Indigenous community governance are involved and to work with them in achieving an acceptable balance. This supportive primary relationship should achieve a lot more than an inspectorial mindset, which does not recognise the complex governance environment in which Indigenous community managers operate and which starts from a position of distrust and suspicion. This does not mean, of course, that instances of incompetence, and even corruption, among senior managers in Indigenous community governance will not be found. They will. But they will be understood against a background of the difficulty of the job and in the context of a primary relationship which asks 'what can be done to support these managers?'

In this regard I note that the Northern Territory Department of Local Government, Housing and Sport has in the last couple of years begun appointing Community Development Officers to work with Indigenous community organisations in a more supportive role. Such officers often now attend Council meetings and act as an external resource person for senior managers in Indigenous community governance as they attempt to progress issues between Council meetings. In many ways I think this is a more important development for Indigenous community governance in the Northern Territory than the push towards larger regional local governments. This more supportive and understanding relationship between the officers of the Northern Territory Local Government Department and the Indigenous community governments which it funds and regulates is a major step towards overcoming isolated managerialism, which other government agencies at the Commonwealth and State/Territory level of Australian government could well add to and emulate.

One other way to overcome isolated managerialism would be to develop more lateral relations between small Indigenous community governments and local governments elsewhere in Australia. These arrangements could offer things as simple as staff cover during leave, or managerial and professional development through short-term placements in one organisation from the other. They could also offer things such as financial and administrative system support and a general sense of perspective that while every local government is unique, there is also a great similarity in what these organisations do and contend with.

Conceptually, overcoming isolated managerialism could be related to what one recent contribution to the Australian Journal of Public Administration saw as developing a 'theory of coherence and mutual accountability' in the 'integrity systems' of public decision making (Sampford, Smith and Brown 2005). These authors want to replace the 'Greek temple' metaphor of integrity systems, involving an image of several different pillars holding up a roof, with a 'bird's nest' image, involving far larger numbers of links or twigs of mutual accountability and support. Following Mulgan, they want to envisage multiple relationships of mutual accountability between guardians of the public interest in interlinked networks (Mulgan 2003). Each mutual accountability link, or twig in the bird's nest, is on its own fragile and insufficient, but together with 
the large number of other such links or twigs, it develops a structure of surprising strength and support for the individual decision maker who sits within it. This is what is required to overcome isolated managerialism in Indigenous community governance and to ensure that senior managers in this difficult governance environment are supported to be good, rather than left alone to discover the pitfalls of their position, then belatedly condemned for being bad. 


\section{REFERENCES}

Ah Kit, J. 2002. 'Ministerial statement', Minister Assisting the Chief Minister on Indigenous Affairs, 7 March, available at <http://www.nt.gov/ocm/speeches/20020305_ahkit_aboriginal.shtml>.

Braham, L. 1999. 'Local government-the next step: Ministerial statement', Minister for Local Government, 17 February, available at <http:// www.nt.gov.au/dhlg/local gov/minstat.shtml>.

Folds, R. 2001. Crossed Purposes: The Pintupi and Australia's Indigenous Policy, University of New South Wales Press, Sydney.

Galligan, B. 1984. 'The state in Australian political thought', Politics, 19 (2): 82-92.

Hancock, W.K. 1961. Australia, Jacaranda, Brisbane [first published 1930].

Hindess, B. 2004. Corruption and Democracy in Australia, Report No. 3, Democratic Audit of Australia, ANU, Canberra.

Martin, D. 1995. 'Money, business and culture: Issues for Aboriginal economic policy', CAEPR Discussion Paper No. 101, CAEPR, ANU, Canberra.

Mulgan, R. 2003. Holding Power to Account: Accountability in Modern Democracies, Palgrave Macmillan, Basingstoke \& New York.

Sampford, C., Smith, R. and Brown, A. 2005. 'From Greek temple to bird's nest: towards a theory of coherence and mutual accountability for national integrity systems', Australian Journal of Public Administration, 64 (2): 96-108.

Sanders, W. 1988. 'The CDEP scheme: bureaucratic politics, remote community politics and the development of an Aboriginal 'workfare' program in times of rising unemployment', Politics, 23 (1): 32-47.

_ 2001. 'A regional CDEP for four remote communities? Papunya, Ikuntji, Watiyawanu and Walungurru', CAEPR Discussion Paper No. 224, CAEPR, ANU, Canberra.

2004. 'Thinking about Indigenous community governance', CAEPR Discussion Paper No. 262, CAEPR, ANU, Canberra.

— forthcoming. 'Dispersal, autonomy and scale in Indigenous community governance: some reflections on recent Northern Territory experience', Australian Journal of Public Administration. 


\section{CENTRE FOR ABORIGINAL ECONOMIC POLICY RESEARCH}

\section{PUBLICATIONS}

For information on earlier CAEPR Discussion Papers and Research Monographs please contact:

Publication Sales, Centre for Aboriginal Economic Policy Research, The Australian National University, Canberra, ACT, 0200, Telephone: 02-6125 8211, Facsimile: 02-6125 9730.

Information on CAEPR, copies of many publications that are available for free electronic download, and abstracts or summaries of all CAEPR print publications can be found on the Centre's website at <www.anu.edu.au/caepr/>.

\section{MONOGRAPH SERIES}

Recent CAEPR monographs are available for purchase or free electronic download from the ANU E Press website at $<$ epress.anu.edu.au/>.

12. Fighting Over Country: Anthropological Perspectives, D.E. Smith and J.D. Finlayson (eds), 1997.

13. Connections in Native Title: Genealogies, Kinship and Groups, J.D. Finlayson, B. Rigsby and H.J. Bek (eds), 1999.

14. Land Rights at Risk? Evaluations of the Reeves Report, J.C. Altman, F. Morphy and T. Rowse (eds), 1999.

15. Unemployment Payments, the Activity Test and Indigenous Australians: Understanding Breach Rates, W. Sanders, 1999.

16. Why Only One in Three? The Complex Reasons for Low Indigenous School Retention, R.G. Schwab, 1999.

17. Indigenous Families and the Welfare System: Two Community Case Studies, D.E. Smith (ed.), 1999.

18. Ngukurr at the Millennium: A Baseline Profile for Social Impact Planning in South East Arnhem Land, J. Taylor, J. Bern and K.A. Senior, 2000.

19. Aboriginal Nutrition and the Nyirranggulung Health Strategy in Jawoyn Country, J. Taylor and N. Westbury, 2000.

20. The Indigenous Welfare Economy and the CDEP Scheme, F. Morphy and W. Sanders (eds), 2001.

21. Health Expenditure, Income and Health Status among Indigenous and Other Australians, M.C. Gray, B.H. Hunter and J. Taylor, 2002.

22. Making Sense of the Census: Observations of the 2001 Enumeration in Remote Aboriginal Australia, D.F. Martin, F. Morphy, W.G. Sanders and J. Taylor, 2002.

23. Aboriginal Population Profiles for Development Planning in the Northern East Kimberley, J. Taylor, 2003.

24. Social Indicators for Aboriginal Governance: Insights from the Thamarrurr Region, Northern Territory, J. Taylor, 2004.

25. Indigenous people and the Pilbara mining boom: A baseline for regional participation, J. Taylor and B. Scambary, 2005. 


\section{RECENT DISCUSSION PAPER SERIES}

Recent CAEPR Discussion Papers are available for purchase or free electronic download from the CAEPR website at $<$ www.anu.edu.au/caepr/>.

257/2003 The realities of Indigenous adult literacy acquisition and practice: Implications for capacity development in remote communities, I. Kral and R.G. Schwab.

258/2003 An Indigenous learning community in the ACT? Opportunity, context and rationale, D. Sutherland.

259/2004 Careers and aspirations: Young Torres Strait Islanders, 1999-2003, W.S. Arthur, J.P. Hughes, V. McGrath and E. Wasaga.

260/2004 Indigenous people in the Alice Springs town camps: The 2001 Census data, W. Sanders.

261/2004 Taming the social capital Hydra? Indigenous poverty, social capital theory and measurement, B. Hunter.

262/2004 Thinking about Indigenous community governance, W. Sanders.

263/2004 Patterns of Indigenous job search activity, B.H. Hunter and M.C. Gray.

264/2004 Indigenous people in the Murray-Darling Basin: A statistical profile, J. Taylor and N. Biddle.

265/2004 From Gove to governance: Reshaping Indigenous governance in the Northern Territory, D.E. Smith.

266/2004 Indigenous socioeconomic change 1971-2001: A historical perspective, J.C. Altman, N. Biddle, and B.H. Hunter.

267/2004 Mapping Indigenous education participation, N. Biddle, B.H. Hunter and R.G. Schwab.

268/2004 Torres Strait elections, 2000 and 2004: Changes in political leadership and style?, W. Sanders.

269/2004 Regulating social problems: The pokies, the Productivity Commission and an Aboriginal community, M. Brady.

270/2004 A profit-related investment scheme for the Indigenous Estate, J.C. Altman and M.C. Dillon.

271/2005 Policy issues for the Community Development Employment Projects scheme in rural and remote Australia, J.C. Altman, M.C. Gray and R. Levitus.

272/2005 The economic value of wild resources to the Indigenous community of the Wallis Lake catchment, M.C. Gray, J.C. Altman and N. Halasz.

273/2005 Bridging the digital divide: the role of community online access centres in Indigenous communities, A. Daly.

274/2005 Indigenous job search success, M.C. Gray and B.H. Hunter.

275/2005 Housing tenure and Indigenous Australians in remote and settled areas, W. Sanders.

276/2005 Land rights and development reform in remote Australia, J.C. Altman, C. Linkhorn and J. Clarke.

277/2005 Tracking change in the relative economic status of Indigenous people in New South Wales, J. Taylor.

278/2005 Capacity development in the international development context: Implications for Indigenous Australia, J. Hunt. 


\section{RECENT WORKING PAPER SERIES}

CAEPR Working Papers are available for free electronic download from the CAEPR website at <www.anu.edu.au/caepr/>.

12/2002 Indigenous Australians and competition and consumer issues: An interim review of the literature and an annotated bibliography, J.C. Altman, S. McDonnell, and S. Ward.

13/2002 The rise of the CDEP scheme and changing factors underlying Indigenous employment, B.H. Hunter.

14/2002 Institutional factors underpinning Indigenous labour force participation: The role of the CDEP scheme and education, B.H. Hunter.

15/2002 Generating finance for Indigenous development: Economic realities and innovative options, J.C. Altman.

16/2002 The spatial context of Indigenous service delivery, J. Taylor.

17/2002 The potential use of tax incentives for Indigenous businesses on Indigenous land, O. Stanley.

18/2002 Banking on Indigenous communities: Issues, options, and Australian and international best practice, S. McDonnell and N. Westbury.

19/2002 One size fits all?: The effect of equivalence scales on Indigenous and other Australian poverty, B.H. Hunter, S. Kennedy and N. Biddle.

20/2003 Caring for country and sustainable Indigenous development: Opportunities, constraints and innovation, J.C. Altman and P.J. Whitehead.

21/2003 Chasing the money story: An evaluation of the Tangentyere Bank Pilot Project and its relevance to Indigenous communities in central Australia, S. McDonnell.

22/2003 Developing an Indigenous Arts Strategy for the Northern Territory: Issues paper for consultations, J.C. Altman.

23/2003 A new model of inclusion? Centrelink's development of income support service delivery for remote Indigenous communities, W. Sanders.

24/2004 Early Indigenous engagement with mining in the Pilbara: Lessons from a historical perspective, S. Holcombe.

25/2004 Socio-political perspectives on localism and regionalism in the Pintupi Luritja region of central Australia: Implications for service delivery and governance, S. Holcombe.

26/2004 Indigenous household structures and ABS definitions of the family: What happens when systems collide, and does it matter?, F. Morphy.

27/2005 The Djelk Ranger Program: An outsider's perspective, M.J. Cochrane.

$28 / 2005$ The opportunity costs of the status quo in the Thamarrurr Region, J. Taylor and O. Stanley.

29/2005 Researching Australian Indigenous governance: A methodological and conceptual framework, D.E. Smith.

30/2005 'You got any Truck?' Vehicles and decentralised mobile service-provision in remote Indigenous Australia, W. Fogarty. 